\title{
CISC CONTROLS AND THE UNION/NON-UNION WAGE RATIO
}

\author{
David Shulenburger, Robert A. McLean, Sara B. Rasch ${ }^{1}$
}

\section{Introduction}

The late 1960's witnessed relatively high rates of change in the hourly wages of craftsmen in the contract construction industries. The belief that these increases in construction costs were passed on to other sectors of the economy and were, thus, a driving force in the inflationary process led to several efforts to contain construction wages. The first of these was the formation of the Construction Industry Collective Bargaining Commission (CICBC). Composed of labor and management representatives, the CICBC met periodically during the era of wage-price guidelines and served as a forum for discussion of wage moderation.

In 1971 , the CICBC was replaced by the Construction Industry Stabilization Committee (CISC), empowered by executive order to review all negotiated wage agreements in the construction industries and to disallow those that were deemed excessive. An important question is whether negotiated settlements were indeed moderated by the CISC. Our goal in this paper is to investigate that question, focusing on whether union/non-union wage ratios were different during the CISC period from what they would have been in the absence of controls.

${ }^{1}$ David Shulenburger and Robert McLean are professor and associate professor respectively in the School of Business at the University of Kansas. Sara B. Rasch is an assistant professor at Memphis State University.

The research reported here was supported by the Office of Construction Industry Servicc:. U.S. Depas ument of Labor. Hugh Conway and Tom Mobley of that office were especially helpful. Conclusions drawn and opinions expressed are those of the authors and cio not represent the position of the U.S. Department of Labor or any of its officials. 
One might believe that negotiated wage settlements were easier to control than non-union wages because of their greater visibility and of the difusion of decision making in the non-union construction industry. If that were the case, the union/non-union wage differential would have been depressed by CISC controls. We found, however, the opposite to be true. While we urge caution in interpreting our results, our simulation suggests that unionization served to shelter union construction craftsmen from the full effects of wage controls.

\section{Sources of Variation in the Wage Ratio}

One cannot know for certain what the union/non-union wage ratio would have been during 1971-74 had the CISC controls not obtained. One can, however, derive an estimate of those unobservable ratios by examining the determinants of the union/non-union wage ratio for the post-control period.

Following Rosen [1969] and Welch [1980], we specified and estimated an equation to account for the variation in the ratio of union to non-union wages. Rosen and Welch found the proportion of the relevant labor force unionized to be a major factor in determining that ratio. Indeed, to the extent that proportion is inversely related to the availability of non-union substitutes for union labor, its inclusion is demanded by the Marshall-Hicks [1927, 1963] analysis of union bargaining power. We also included the square of the degree of unionization and the rate of change of the degree of unionization in our estimating equation. We anticipated that the coefficient on the degree of unionization and its rate of change would be positive and that the coefficient of the degree of unionism squared would be negative.

While Welch included a set of dichotomous variables (one for each city in his sample) to account for inter-metropolitan differences in economic conditions, we specified a set of independent variables to represent market conditions directly. These were: 
percent change in the volume of construction activity over the previous year, (from F. W. Dodge construction data) a measure of the demand for labor in the construction labor market; the general unemployment rate, a measure of excess supply of labor; and average manufacturing wages divided by average construction wages, to represent the incentive for labor to flow from the unorganized segment of the construction labor market to the manufacturing labor market. We anticipated that the coefficient of the change in the volume of construction activity would be greater than zero, that the general unemployment rate would be greater than zero (greater employment depressing wage levels in the unorganized sector to a greater extent than in the organized sector), and that of the manufacturing/craft wage ratio would be negative (non-union construction wages being related to manufacturing wages to a greater extent than are union wages).

We also recognized the role of non-market factors in the wage-setting process. Specifically, we included two variables to account for changes in the structure of collective bargaining. The first of these was a dichotomous variable taking the value of one for those localities in which construction trades engaged in coalition or coordinated bargaining (Cullen and Feinberg 1980). Related research by the authors indicated that the presence of coordinated bargaining may have significant influences on the ability of unions to win wage concessions (see Shulenburger, McLean and Rasch, 1981). Further, the separate crafts involved in construction exhibit different union/non-union wage differentials. These differences reflect differentially great abilities to balkanize labor markets, and differentially great importances of union-sponsored training in the wage determination process. The coefficients estimated for these craft dummies, then, represent differentials in the dependent variable for the craft indicated relative to the omitted craft, carpenters.

The dependent variable is the natural logarithm of the ratio of union to non-union wages in contract construction. Each observation is a single craft within a metropolitan area. Data on area 
market conditions are derived from local economic conditions.

The dependent variable requires further discussion. As was true for the estimates derived by Welch [1980], we were limited by availability of data in our derivation of the union/non-union wage ratio. Our measure of the wage, in both the union and nonunion cases is the hourly direct wage rate, omitting all fringe benefits. For the union case, these data were provided by the Office of Construction Industry Services, from its records of negotiated settlements. For the non-union case, we were limited to data from the Bureau of Labor Statistics' special surveys of construction wages conducted in 1972, 1973, 1976, and 1977.

Ideally, the "wage" ratio should include fringe benefits in both its numerator and its denominator. This is not possible, due to the nature of the B.L.S. data. As Welch [1980, p. 156] argues, fringe benefits are highly correlated with the level of money wages. Thus, the omission of fringe benefits should generate no significant bias in the wage ratio employed.

The estimating equation specified, then, is of the following form:

$$
\text { (1) } \begin{aligned}
1 n W_{i j}= & c_{0} c_{1} U_{i j}+c_{2} U^{2}{ }_{i j}+c_{3}(\% A U)_{i j}+c_{4} V_{j}+c_{5} R_{j}+ \\
& c_{6} M_{i j}+c_{7} B_{i j}+c_{8} C+\ldots+c_{n} C+e_{i j}
\end{aligned}
$$

where

$1 \mathrm{nW}-$ - natural log of union $\div$ non-union craft wages

$\mathrm{U}--$ percent unionized

$\mathrm{V}--$ percent change in the volume of construction activity since the previous year

\%AU - - 1973-1977 percent change in the proportion unionized

$\mathbf{R}$-- general unemployment rate

$M$ - - average manufacturing wages divided by craft wages

B -- dummy variable for coordinated bargaining participation

C - - craft union dummy variables 
Table 1 lists the estimates of the parameters of the determinants of the union/non-union wage ratio for the four years for which B.L.S. special survey data are available. A detailed discussion of these estimates and of the differences between our estimates and those of Welch [1980] can be found in Shulenburger, McLean, and Rasch [1981]. For the purpose of this discussion, we note only the differences among the four sets of estimates in the number of observations on which the estimates were based.

While the equation estimated for 1976 may appear to be the best of the lot for evaluating the effect of CISC controls of the wage ratio, we are reluctant to use it for that purpose. Only thirty observations were available for that year. Thus, the estimates are based on only twelve degrees of freedom. We have based our analysis on the 1977 estimates, and have compared our results against a similar analysis with the 1972 and 1973 results.

\section{Simulating the Effect of CISC Controls}

Our 1977 coefficients for the determinants of the union/nonunion wage ratio provide an estimate of what that ratio would have been in the absence of controls in 1972 and 1973 (after substituting the 1972 and 1973 values of the independent variables). Thus, we can simulate the effect of controls on the wage ratio. Table 2 reports the results of that simulation. As shown by the first row of the table, the 1977 equation (with 1977 values substituted for the independent variables) predicts the 1977 value of the mean union/non-union wage ratio quite well. When 1972 and 1973 values of the independent variables are substituted in the 1977 equation, however, it underpredicts the actual mean wage ratios by a large percentage. That is, the relationships which explain the 1977 wage ratio suggests that, given conditions prevailing in 1972 , the mean ratio of union to non-union wage in the construction sample would have been 16.7 percent lower than it actually was in 1972 . 
TABLE 1

Dependent Variable: Natural Log of UnioniNon-Union Wage Ratio

\begin{tabular}{|c|c|c|c|c|}
\hline Variable Vear & 1972 & 1973 & 1976 & 1977 \\
\hline Coordinated BargainIng & $\begin{array}{r}-.070 \\
(1.47)\end{array}$ & $\begin{array}{l}-.045 \\
(.04)\end{array}$ & $\begin{array}{r}.036 \\
(.54)\end{array}$ & $\begin{array}{r}-.027 \\
(.58)\end{array}$ \\
\hline$\because$ Untonlzed & $\begin{array}{r}.544 \\
(.73)\end{array}$ & $\begin{array}{r}.339 \\
(.65)\end{array}$ & $\begin{array}{l}.210 \\
(.55)\end{array}$ & $(1.67)$ \\
\hline $\begin{array}{l}1973-1977 \text { z Change } \\
\text { III Unionlzed }\end{array}$ & -- & $\rightarrow$ & -- & $\begin{array}{l}.501 \\
(.82)\end{array}$ \\
\hline Manufacturing Wage Rat lo & $\begin{array}{l}.209 \\
(.59)\end{array}$ & $\frac{-.568}{(2.20) * *}$ & $\begin{array}{l}-1.055 \\
(5.03)\end{array}$ & $\begin{array}{l}-.021 \\
(.089)\end{array}$ \\
\hline $\begin{array}{l}\text { Percent Change In voluse } \\
\text { of Cinstruction }\end{array}$ & --- & $(2.53) \star * t$ & $(1.23)$ & $(1.78)$ \\
\hline Uneop L oywent & $\begin{array}{l}.013 \\
(.94)\end{array}$ & $\begin{array}{r}-.005 \\
(.36)\end{array}$ & $\begin{array}{r}-.016 \\
(1.10)\end{array}$ & $\begin{array}{c}.037 \\
(2.014)\end{array}$ \\
\hline Bricklayer: & $\begin{array}{l}-.301 \\
(2.042) * t\end{array}$ & $\begin{array}{l}-.242 \\
(3.24) * 4\end{array}$ & $\begin{array}{r}-.024 \\
(.23)\end{array}$ & $\begin{array}{l}-.157 \\
(2.02)\end{array}$ \\
\hline Cement Masons & $\begin{array}{l}-.35 \\
(.46)\end{array}$ & $(1.27)$ & $(1.56)$ & $(2.58) *$ \\
\hline Electrician: & $\begin{array}{l}.35 \\
(.50)\end{array}$ & $\begin{array}{r}.073 \\
(1.27)\end{array}$ & $(2.25) *$ & $(1.91)$ \\
\hline Iron Werker: & $-\cdots$ & - & $\begin{array}{l}.254 \\
(2.14)=n\end{array}$ & - \\
\hline Laborers & $\begin{array}{c}-.076 \\
(.80)\end{array}$ & $(3.16)^{.228}$ & $(6.18) *$ & $\begin{array}{c}.007 \\
(1.91)\end{array}$ \\
\hline Painter: & -- & - & $\frac{.198}{(2.87)^{*}}$ & -- \\
\hline Plpeficters & $\begin{array}{r}.052 \\
(.57)\end{array}$ & $\begin{array}{l}.064 \\
(.67)\end{array}$ & $\begin{array}{r}-.062 \\
(.77)\end{array}$ & $\begin{array}{l}.016 \\
(.10)\end{array}$ \\
\hline Plumbers & $\begin{array}{l}-.050 \\
(.57)\end{array}$ & $\begin{array}{r}.032 \\
(.54)\end{array}$ & $\begin{array}{l}-.029 \\
(.41)\end{array}$ & $\begin{array}{l}.016 \\
(.29)\end{array}$ \\
\hline Rnofers & $\begin{array}{l}.054 \\
(.36)\end{array}$ & $\begin{array}{l}.038 \\
(.64)\end{array}$ & $\begin{array}{r}-.001 \\
(.00)\end{array}$ & $\begin{array}{r}-.012 \\
(1.11)\end{array}$ \\
\hline Sheet Metal Workers & $\begin{array}{r}.043 \\
(.47)\end{array}$ & $\begin{array}{c}.167 \\
(2.88) * *\end{array}$ & $\begin{array}{r}.066 \\
(.07)\end{array}$ & $\begin{array}{l}.119 \\
(2.15)^{n}\end{array}$ \\
\hline Constane & .216 & .642 & .909 & .295 \\
\hline $\begin{array}{l}\tilde{R}^{2} \\
\mathrm{~N}\end{array}$ & ${ }_{48}^{1.83}$ & $98^{3.84 * \hbar k}$ & ${ }_{10}^{6.96}$ & $3_{64}^{.42}$ \\
\hline
\end{tabular}

t-statsotics are in parenthesps.

-sipmificane at. 10 level

*hagnificant at .05 level

A**significant at. 01 level 
To check this result, we substituted 1977 mean values for the independent variables in the 1972 and 1973 equations. The predicting equations for the earlier years substantially overpredicted the wage ratio for the later year. The 1972 equation predicts that the 1977 wage ratio would have been 16.7 percent greater than it actually was, while the 1973 equation predicted a 17.3 percent higher wage ratio.

There are, of course several interpretations of the results of this simulation. There may have been some change in the relationship between union and non-union wages for which we have failed to account. Note however, that the major change in the construction labor market, the decline in the percentage unionized, is well controlled in our model.

The other interpretation of these results (the one that the authors favor) is that the control process itself was the factor accounting for differences between the structural relationships for 1972 and 1973 and that for 1977 . If that were the case, then the effect of CISC controls was to "protect" union construction craftsmen from the wage moderating effects of the period of economic controls.

Reid [1981] found the controls process to have had a significant (if inconsistent over time) effect on rates of change in aggregate wage levels. The results of our simulation suggest that non-union construction craftsmen shared in that aggregate wage moderation to a greater extent than did union construction craftsmen.

\section{Conclusions}

Claims of success have been made for the CISC. Mills [1980, p. 85], for example, stated, "During the major part of the program, (1972-73), wage and benefit increases negotiated in collective bargaining agreements were substantially reduced." The 
64

TABLE 2

Simulation of Impact of Controls

$\begin{array}{cccc}\text { Year } & \begin{array}{c}\text { Predicted Mean } \\ \text { Wage Ratio }\end{array} & \begin{array}{c}\text { Actual Mean } \\ \text { Wage Ratio }\end{array} & \begin{array}{c}\text { Percent } \\ \text { Difference }\end{array}\end{array}$

1977

1.409

1.419

$+.7 \%$

1972

1.282

1.489

$+16.7 \%$

1973

1.195

1.445

$+17.3 \%$ 
results reported here do not dispute Mills' claim directly. Rather, our simulation suggests that wage-price controls were more effective in reducing construction increases outside the union sector than they were in moderating negotiated wage settlements. 


\section{REFERENCES}

1. Cullen, Donald E. and Louis Feinberg, "The Bargaining Structure in Construction: Problems and Prospects." Washington, D.C.: U.S. Department of Labor, LaborManagement Services Administration, 1980.

2. Hicks, J.R., The Tbeory of Wages, second edition. London: Macmillan, 1963.

3. Marshall, Alfred, Principles of Economics, eighth edition. London: Macmillan, 1927.

4. Mills, D. Quinn, "Construction." In Gerald G. Somers (editor), Collective Bargaining: Contemporary American Experience, Madison, Wisconsin: Industrial Relations Research Association, 1980, pp. 49-97.

5. Reid, Frank, "Control and Decontrol of Wages in the United States: An Empirical Analysis," American Economic Review, Vol. 71, No. 1 (March 1981): pp. 108-120.

6. Rosen, Sherwin, "Trade Union Power, Threat Effects, and the Extent of Organization." Review of Economic Studies, Vol. 36, No. 2 (April 1969): pp. 185-196.

7. Shulenburger, David E., Robert A. McLean, and Sara B. Rasch, "The Construction Wage Determination Process in the 1970's," A Report to the U.S. Department of Labor, Labor-Management Services Administration, Office of Construction Industry Services, August 1981.

8. Welch, Stephen W., "Union-Non-union Construction Wage Differentials," Industrial Relations, Vol. 19, No. 2 (Spring 1980): pp. 152-162. 